\title{
APLIKASI ALGORITMA FLOYD-WARSHALL DENGAN PENDEKATAN MADM DALAM MENENTUKAN RUTE TERPENDEK PENGANGKUTAN SAMPAH
}

\author{
Zulmagfir Buako ${ }^{1 *}$, Lailany Yahya ${ }^{2}$, Novianita Achmad ${ }^{3}$ \\ 1,2,3 Jurusan Matematika, Universitas Negeri Gorontalo, Bone Bolango 96119, Indonesia \\ *Penulis Korespondensi: zmbuako@gmail.com
}

\begin{abstract}
Abstrak
Saat ini masalah kebersihan lingkungan yang disebabkan oleh penumpukan sampah menjadi masalah yang serius bagi setiap masyarakat. Dalam mengatasi masalah ini diperlukan proses pengangkutan sampah yang efisien. Penelitian ini bertujuan mencari rute terpendek pengangkutan sampah di Kota Gorontalo dengan menggunakan Algoritma Floyd Warshall dengan mencari bobot terkecil antar setiap titik (Vertex). Dalam penelitian ini bobot yang digunakan pada iterasi algoritma Floyd Warshall adalah bobot alternatif yang diperoleh dengan pendekatan Multi Attribute Decision Making (MADM). Kriteria penentuan bobot pada MADM menggunakan tiga indikator yang mempengaruhi efisiensi pengangkutan sampah, yaitu jarak,waktu, dan kemacetan. Rute yang digunakan dalam penelitian ini adalah rute kendaraan DumpTruck dengan 17 titik pengangkutan sampah. Setelah diperoleh bobot alternatif dan dilakukan iterasi menggunakan algoritma floyd Warshall diperoleh rute terpendek dengan bobot lintasan terkecil yaitu 110,845.
\end{abstract}

Kata Kunci: Floyd Warshall; Multi Attribute Decision Making; Pengangkutan Sampah

\begin{abstract}
Currently, the problem of environmental hygiene caused by the accumulation of garbage becomes a serious problem for every community. In addressing this problem, an efficient waste transport process is required. This study aims to find the shortest route of garbage transportation in Gorontalo city by using Floyd Warshall Algorithm by finding the smallest weight between each point (Vertex). In this study, the weights used in the Floyd Warshall Iteration Algorithm were Alternative weights obtained by the Multi-Attribute Decision-Making approach (MADM). The criteria for determining weights in MADM use three indicators that affect the efficiency of garbage transportation, namely Distance, time, and congestion. The route used in this study is the dump truck route with 17 garbage transportation points. After obtaining the Alternate weight and iteration using Floyd Warshall algorithm obtained the shortest route with the smallest trajectory weight of 110.845 .
\end{abstract}

Keywords: Floyd Warshall; Multi Attribute Decision Making; Waste Transport

\section{Pendahuluan}

Di era globalisasi seperti saat ini, sampah menjadi masalah serius bagi semua lapisan masyarakat, hal ini dipengaruhi oleh tingginya produktivitas manusia, pertambahan jumlah penduduk, tingginya tingkat konsumtif masyarakat, dan ketersediaan ruang hidup manusia yang terbatas. Di kota Gorontalo, dalam sehari sampah dapat mencapai 73 ton, totalnya 24.359 ton yang dibuang ke TPA Talumelito pada tahun 2017, jumlah ini meningkat bila dibandingkan dengan ratarata produksi sampah per hari di tahun 2016 yang berkisar 67 ton. Masalah penumpukan sampah merupakan salah satu masalah urgent yang harus diantisipasi oleh pemerintah dalam hal ini melalui Dinas Lingkungan Hidup (DLH). Volume sampah yang meningkat dan tidak segera dikelola akan berdampak buruk terhadap lingkungan dan kehidupan masyarakat [1]. 
Matematika merupakan alat untuk menyederhanakan penyajian dan pemahaman masalah. Salah satu cabang dari ilmu matematika adalah teori graf. Graf digunakan untuk merepresentasikan objek-objek diskrit dan hubungan objek-objek tersebut. Dalam teori graf terdapat beberapa algoritma yang dapat digunakan untuk memecahkan permasalahan rute terpendek, antara lain algoritma Dijkstra, algoritma Bellman-Ford [2], algoritma Greedy, algoritma Floyd-Warshall dan lain-lain. Algoritma Floyd-Warshall adalah salah satu algoritma yang paling mudah penerapannya, karena algoritma ini merupakan bagian dari program dinamik yang dapat mencari semua lintasan terpendek masing-masing antara tiap kemungkinan pasang tempat yang berbeda dan sangat efektif digunakan dalam menangani masalah rute optimum. Algoritma Floyd-Warshall merupakan suatu metode yang melakukan pemecahan masalah dengan memandang solusi yang akan diperoleh sebagai suatu keputusan yang saling terkait dan akan memilih satu jalur terpendek dari beberapa alternatif jalur yang telah dihasilkan dari proses kalkulasi. Artinya solusi-solusi tersebut dibentuk dari solusi yang berasal dari tahap sebelumnya dan ada kemungkinan solusi lebih dari satu dalam pengertian lain algoritma ini menghitung bobot terkecil dari semua jalur yang menghubungkan sebuah pasangan titik dan melakukannya sekaligus untuk semua pasangan titik demi titik hingga mencapai titik tujuan dengan jumlah bobot yang paling minimum [3].

Pada penelitian sebelumnya telah dibahas mengenai implementasi algoritma Floyd-Warshall dalam menentukan rute terpendek diantaranya dalam menentukan pemodelan jaringan pariwisata, pencarian apotek, panduan jalur angkutan umum, sistem informasi fasilitas instansi, menentukan jalur evakuasi tsunami [4]-[9]. Perbedaan penelitian ini dengan penelitian sebelumnya, pada penelitian ini untuk dapat memilih rute terpendek, maka saya menambahkan indikator yang mempengaruhi perjalanan truk pengangkut sampah. Indikator indikator tersebut antara lain, jarak antar titik, waktu perjalanan dan kemacetan dari rute tersebut. Ketiga indikator ini selanjutnya akan diselesaikan dengan pendekatan Multiple Attribute Decision Making (MADM), pendekatan ini digunakan untuk menyatukan bobot masing masing indikator sehingga diperoleh bobot yang memuat ketiga indikator [10][11][12]. Setelah diperoleh bobot lintasan alternatif, selanjutnya dilskukan iterasi dengan Algoritma Floyd Warshall, algoritma ini digunakan untuk mencari semua lintasan terpendek masing-masing antara tiap kemungkinan pasang tempat yang berbeda dan sangat efektif digunakan dalam menangani masalah rute optimum. Kemudian dari bobot yang diperoleh dari hasil iterasi dapat dibentuk rute terpendek dengan mencari lintasan (edge) dengan bobot terkecil antar setiap pasangan titik (vertex).

\section{Metode Penelitian}

Pada penelitian ini data lintasan yang digunakan adalah data primer yang diperoleh langsung melalui observasi dengan Software Google Maps, Serta data sekunder diperoleh dari penelitian sebelumnya [1]. Adapun tahapan pengolahan data dimulai dengan memodelkan data yang diperoleh ke dalam bentuk graf penelitian, selanjutnya menganalisis bobot indikator yang digunakan yaitu jarak, waktu, dan kemacetan ketiga bobot ini kemudian dirasionalisasi kedalam range yang sama (1-10) kemudian ketiga bobot indikator akan diubah menjadi satu bobot (bobot alternatif) dengan pendekatan Multiple Attribute Decision Making (Tabel 4). Bobot yang diperoleh kemudian digunakan sebagai bobot lintasan (edge) dalam proses iterasi algoritma Floyd-Warshall. Hasil akhir iterasi algoritma floyd warshall kemudian di tampilkan kembali ke dalam bentuk graf hasil penelitian (Gambar 2). Rute terpendek (optimum) Diperoleh dengan menganalisis bobot terkecil antar setiap edge yang menghubungkan masing masing titik (vertex) dengan ketentuan tidak terjadi loop (setiap lintasan (edge) hanya dapat dilalui sekali).

\section{Hasil dan Pembahasan}

\subsection{Pengumpulan Data}

Dalam penelitian ini penulis menggunakan rute armada dump truck dengan 17 layanan pengangkutan sampah. Berikut data layanan yang digunakan dalam penelitian ini, disajikan pada Tabel 1. 
Tabel 1. Daftar Layanan Pengangkutan Sampah

\begin{tabular}{cl}
\hline No. & \multicolumn{1}{c}{ Alamat } \\
\hline 1. & Dinas Lingkungan Hidup \\
2. & Jl. Raja Eyato \\
3. & JL. Suprapto \\
4. & JL. MT Haryono \\
5. & JL. 23 Januari \\
6. & JL. S.Parman \\
7. & JL. ST. Hasanudin \\
8. & JL. Melati \\
9. & JL. Kancil \\
10. & JL. Gunung Agung \\
11. & Jl. Gunung Tilongkabila \\
12. & JL. Gunung Boliyohuto \\
13. & Jl. Gunung Lokon \\
14. & JL. Gunung Krakatau \\
15. & JL. Gunung Katamso \\
16. & JL. Mawar \\
17. & JL AR Koniyo \\
\hline
\end{tabular}

Berdasarkan data layanan pengangkutan sampah seperti yang disajikan pada Tabel 1 kemudian dapat dibentuk graf berdasarkan opsi lintasan yang menghubungkan antar titik.

\subsection{Graf Penelitian}

Berdasarkan data layanan pada Tabel 1, dapat diperoleh graf penelitian sebagai berikut.

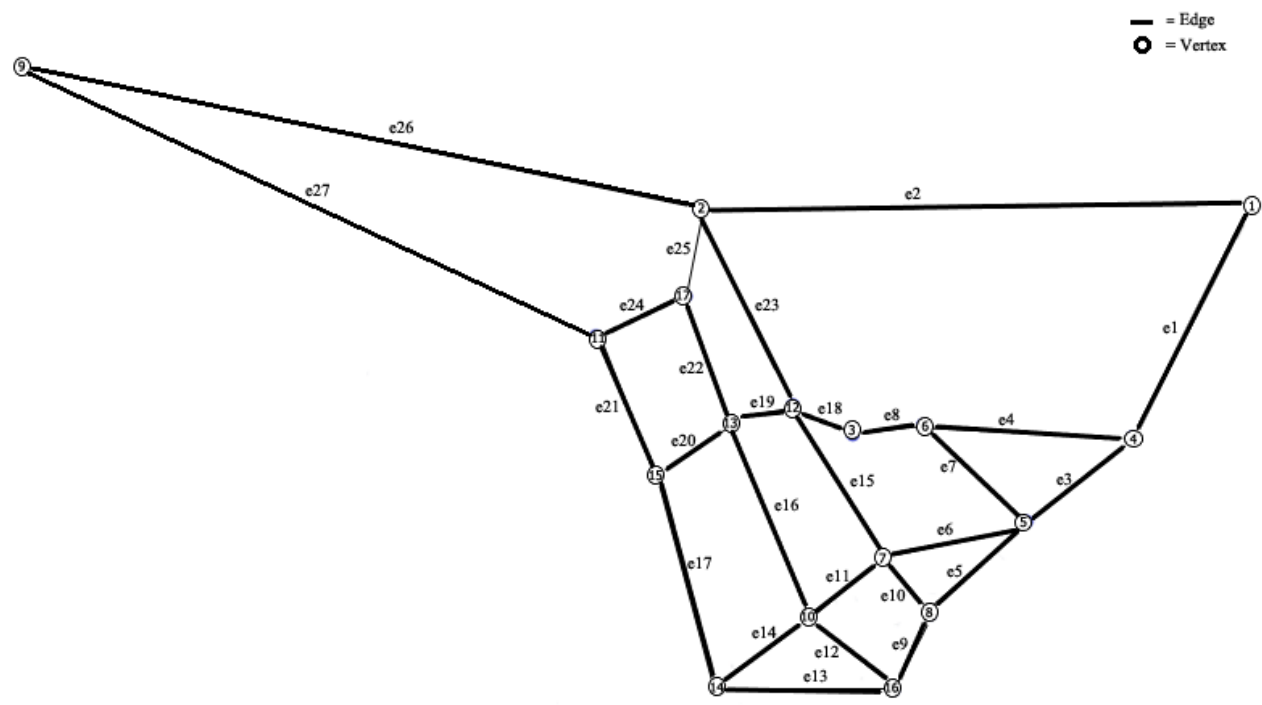

Gambar 1. Graf penelitian

Graf penelitian pada Gambar 1 diperoleh dengan menghubungkan setiap titik dengan menggunakan Software Google Maps.

\subsection{Indikator}

Indikator yang digunakan pada penelitian ini terdiri atas indikator jarak,waktu, dan kemacetan. Indikator jarak diperoleh memalui pengukuran jarak antar titik, indikator waktu adalah data yang menyatakan durasi waktu perjalanan antar vertex, dan indikator kemacetan adalah data yang menggambarkan tingkat kemacetan tiap ruas jalan (edge) Ketiga data indikator diperoleh 
dengan observasi melalui software Google Maps. Kemudian data yang diperoleh dirasionalisasi kedalam range yang sama (1-10). Berikut adalah rekapan data masing masing indikator setelah dilakukan rasionalisasi kedalam range yang sama (1-10), ditampilkan pada Tabel 2.

Tabel 2. Data Indikator

\begin{tabular}{cccc}
\hline Edge. & Skor Jarak & Skor Waktu & Skor Kemacetan \\
\hline e1 & 3,448 & 1 & 4 \\
e2 & 8,099 & 5 & 6 \\
e3 & 2,386 & 1 & 6 \\
e4 & 3,437 & 2 & 3 \\
e5 & 2,811 & 2 & 2 \\
e6 & 2,397 & 1 & 8 \\
e7 & 2,425 & 1 & 6 \\
e8 & 1,000 & 1 & 8 \\
e9 & 1,911 & 2 & 5 \\
e10 & 1,659 & 1 & 3 \\
e11 & 1,592 & 1 & 6 \\
e12 & 2,749 & 3 & 7 \\
e13 & 2,950 & 3 & 6 \\
e14 & 1,877 & 1 & 6 \\
e15 & 2,654 & 2 & 4 \\
e16 & 2,978 & 2 & 5 \\
e17 & 3,040 & 3 & 3 \\
e18 & 1,279 & 1 & 5 \\
e19 & 1,262 & 1 & 4 \\
e20 & 1,463 & 1 & 5 \\
e21 & 2,565 & 1 & 3 \\
e22 & 2,453 & 1 & 5 \\
e23 & 3,113 & 1 & 6 \\
e24 & 1,665 & 1 & 3 \\
e25 & 1,491 & 1 & 4 \\
e26 & 10,000 & 5 & 6 \\
e27 & 9,105 & 6 &
\end{tabular}

\subsection{Penggabungan Indikator}

Untuk dapat melanjutkan proses iterasi dengan algoritma Floyd Warshall maka akan dibentuk matriks awal $W_{i j}$ untuk itu diperlukan penggabungan bobot ketiga indikator menjadi bobot alternatif. Dalam proses sebelumnya sudah diperoleh data skor masing masing indikator sebagaimana terlampir pada Tabel 2. Penggabungan ketiga indikator ini dilakukan dengan pendekatan MDAM (Multi Atribute Decision Making) dengan metode SAW (Simple Additive Weighting Method). Terdapat beberapa langkah penyelesaian SAW, yaitu :

1. Menentukan kriteria yang dijadikan acuan $(C i)$

Adapun kriteria yang digunkan pada penelitian ini yaitu $\mathrm{C} 1=$ Indikator Jarak, $\mathrm{C} 2=$ Indikator waktu, dan C3 = Indikator kemacetan.

2. Menentukan Rating Kecocokan tiap Indikator.

Rating kecocokan setiap indikator adalah $C 1=4, C 2=3, C 3=3$ artinya setiap indicator mendapat porsi yang berbeda dalam menentukan nilai alternatif.

3. Membuat matriks keputusan berdasarkan indikator $\left(C_{i}\right)$ kemudian melakukan normalisasi matriks dengan persamaan $r_{i j}=\frac{x_{y}}{\operatorname{Max} x_{y}}$. Dengan menyelesaikan langkah ini diperoleh matriks ternormalisasi berikut. 
Tabel 3. Matriks Ternormalisasi

\begin{tabular}{lll}
\hline 0,862 & 0,250 & 1,000 \\
1,000 & 0,617 & 0,741 \\
0,397 & 0,166 & 1,000 \\
1,000 & 0,851 & 0,872 \\
1,000 & 0,711 & 0,711 \\
0,299 & 0,125 & 1,000 \\
0,404 & 0,166 & 1,000 \\
0,125 & 0,125 & 1,000 \\
0,382 & 0,400 & 1,000 \\
0,553 & 0,333 & 1,000 \\
0,265 & 0,166 & 1,000 \\
0,392 & 0,428 & 1,000 \\
0,491 & 0,500 & 1,000 \\
0,312 & 0,166 & 1,000 \\
0,663 & 0,500 & 1,000 \\
0,978 & 0400 & 1,000 \\
1,000 & 0,986 & 0,986 \\
0,255 & 0,200 & 1,000 \\
0,315 & 0,250 & 1,000 \\
0,292 & 0,200 & 1,000 \\
0,855 & 0,333 & 1,000 \\
0,490 & 0,200 & 1,000 \\
0,518 & 0,500 & 1,000 \\
0,555 & 0,333 & 1,000 \\
0,372 & 0,250 & 1,000 \\
1,000 & 0,500 & 0,600 \\
1,000 & 0,658 & 0,658 \\
\hline & &
\end{tabular}

4. Nilai alternatif diperoleh dengan proses penjumlahan dari perkalian matriks ternormalisasi dengan vektor bobot (Bobot rating kecocokan). $V_{i}=\sum_{j=1}^{n} W_{j} r_{i j}$ Dimana $V_{i}$ adalah nilai alternatif, $W_{j}$ bobot rating kecocokan, dan $r_{i j}$ adalah matriks ternormalisasi.

Tabel 4. Nilai Alternatif

\begin{tabular}{cccccc}
\hline Edge. & $\begin{array}{c}\text { Pasangan titik } \\
\text { (Vertex) }\end{array}$ & Nilai Alternatif & Edge. & $\begin{array}{c}\text { Pasangan titik } \\
\text { (Vertex) }\end{array}$ & Nilai Alternatif \\
\hline e1 & V1-V4 & 7,198 & e15 & V7-V12 & 7,152 \\
e2 & V1-V2 & 8,074 & e16 & V10-V13 & 8,112 \\
e3 & V4-V5 & 5,086 & e17 & V15-V14 & 9,916 \\
e4 & V4-V6 & 8,089 & e18 & V3-V12 & 4,620 \\
e5 & V5-V8 & 8,266 & e19 & V12-V13 & 5,010 \\
e6 & V5-V7 & 4,571 & e20 & V13-V15 & 4,768 \\
e7 & V5-V6 & 5,114 & e21 & V15-V11 & 7,419 \\
e8 & V6-V3 & 3,875 & e22 & V13-V17 & 5,560 \\
e9 & V8-V16 & 5,728 & e23 & V12-V2 & 6,572 \\
e10 & V8-V7 & 6,211 & e24 & V11-V17 & 6,219 \\
e11 & V7-V10 & 4,588 & e25 & V17-V2 & 5,238 \\
e12 & V16-V10 & 5,852 & e26 & V2-V9 & 7,300 \\
e13 & V16-V14 & 6,464 & e27 & V11-V9 & 7,948 \\
e14 & V10-V14 & 4,746 & & & \\
\hline
\end{tabular}


Setelah memperoleh nilai alternatif yang merupakan gabungan dari ketiga indikator, maka nilai tersebut digunakan dalam perhitungan algoritma Floyd-Warshall sebagai bobot. Berikut Langkah langkah perhitungan dengan menggunakan algoritma Floyd Warshall.

1. Langkah pertama dalam perhitungan ini yaitu merepresentasikan Graf yang ada menjadi suatu matriks Berskor. dimana skor untuk masing masing edge adalah

$$
W_{i j}=\left\{\begin{array}{cr}
0, & \text { Jika } i=j \\
W_{i j} & \text { Jika } i \neq j \text { dan } W_{i j} \in E \\
\infty & \text { Jika } i \neq j \text { dan } W_{i j} \notin E
\end{array}\right.
$$

2. Langkah kedua adalah melakukan iterasi. Untuk setiap sel matriks $\mathrm{W}$ dicek Apakah $W_{i j}>W_{i k}+W_{k j}$. Jika ya, Maka $W_{i j}$ diganti dengan $W_{i k}+W_{k j}$.

Proses iterasi dilakukan dengan mencari bobot terkecil antar semua titik, dan dilakukan berulang dengan $k=1$ - 16. Untuk memudahkan proses iterasi dilakukan dengan bantuan perangkat lunak. Dalam penelitian ini proses iterasi diselesaikan dengan menggunakan Software MATLAB. Berikut adalah rekapan hasil matlab untuk iterasi k=17.

Tabel 5. Hasil akhir iterasi algoritma Floyd-Warshall

\begin{tabular}{|c|c|c|c|c|c|c|c|c|}
\hline Jertex & 1 & 2 & 3 & 4 & 5 & 6 & 7 & 8 \\
\hline 1 & 0 & 8,074 & 19,162 & 7,198 & 12,284 & 15,287 & 16,855 & 20,510 \\
\hline 2 & 8,074 & 0 & 11,192 & 15,272 & 18,295 & 15,067 & 13,724 & 19,935 \\
\hline 3 & 19,171 & 11,192 & 0 & 11,973 & 8,989 & 3,875 & 11,772 & 17,215 \\
\hline 4 & 198 & 15,272 & 11,964 & 0 & 5,086 & 8,089 & 9,657 & 13,312 \\
\hline 5 & 12,284 & 18,295 & 8,989 & 5,086 & 0 & 5,114 & 4,571 & 8,226 \\
\hline 6 & 15,296 & 15,067 & 3,875 & 8,098 & 5,114 & 0 & 9,685 & 13,340 \\
\hline 7 & 16,855 & 13,724 & 11,772 & 9,657 & 4,571 & 9,685 & 0 & 6,211 \\
\hline 8 & 2 & 19,935 & 17,215 & 13,312 & 8,226 & 13,340 & 6,211 & 0 \\
\hline 9 & 15,374 & 7,300 & 18,492 & 22,572 & 25,595 & 22,367 & 21,024 & 27,235 \\
\hline 10 & 25,098 & 18,910 & 17,742 & 17,900 & 12,814 & 17,928 & 10,799 & 4,588 \\
\hline 11 & 19,531 & 11,457 & 21,409 & 26,729 & 28,512 & 25,284 & 23,941 & 24,479 \\
\hline 12 & 14,646 & 6,572 & 4,620 & 16,593 & 11,723 & 8,495 & & 13,363 \\
\hline 13 & 18,872 & 10,798 & 9,630 & 21,603 & 16,733 & 13,505 & 12,162 & 12,700 \\
\hline 14 & 29,884 & 23,656 & 22,488 & 22,646 & 17,560 & 22,674 & 15,545 & 9,334 \\
\hline 15 & 950 & 18,7 & 28,828 & 31,842 & 26 , & 31,870 & 24,741 & 18,530 \\
\hline 16 & 26,238 & 24,762 & 22,943 & 19,040 & 13,954 & 19,068 & 11,939 & 5,728 \\
\hline 17 & 312 & 5,238 & 15,190 & 20,510 & 22,293 & 19,065 & 17,722 & 18,260 \\
\hline 9 & 10 & 11 & 12 & 13 & 14 & 15 & 16 & 17 \\
\hline 15,374 & 443 & 31 & 14,646 & 72 & 6,189 & 26,950 & 26,2380 & 13,312 \\
\hline 7,300 & 312 & 11,457 & 6,572 & 10,798 & 23,058 & 18,876 & 25,663 & 5,238 \\
\hline 18,492 & 16,360 & 21,409 & 4,620 & 9,630 & 21,106 & 28,828 & 22,943 & 15,190 \\
\hline 22,572 & 14,245 & 26,729 & 16,584 & 21,594 & 18,991 & 28,907 & 19,040 & 20,510 \\
\hline 25,595 & 9,159 & 28,512 & 11,723 & 16,733 & 13,905 & 23,821 & 13,954 & 22,293 \\
\hline 22,367 & 14,273 & 25,284 & 8,495 & 13,505 & 19,019 & 28,935 & 19,068 & 19,065 \\
\hline 21,024 & 4,588 & 23,941 & 7,152 & 12,162 & 9,334 & 19,250 & 11,939 & 17,722 \\
\hline 27,235 & 10,799 & 29,527 & 13,363 & 18,373 & 12,192 & 22,108 & 5,728 & 23,933 \\
\hline 0 & 25,612 & 7,948 & 13,872 & 18,098 & 24,563 & 15,367 & 31,027 & 12,538 \\
\hline 26,210 & 0 & 19,890 & 13,122 & 8,112 & 4,746 & 14,662 & 10,316 & 13,672 \\
\hline & 19,891 & 0 & 16,789 & 11,779 & 16,615 & 7,419 & 23,079 & 6,219 \\
\hline 13,872 & 17,740 & 16,789 & 0 & 5,010 & 16,486 & 24,208 & 19,091 & 10,570 \\
\hline 18,098 & 8,112 & 11,779 & 5,010 & 0 & 12,858 & 19,198 & 18,428 & 5,560 \\
\hline 25,283 & 4,746 & 17,335 & 17,686 & 12,858 & 0 & 9,916 & 6,464 & 18,418 \\
\hline
\end{tabular}




\begin{tabular}{ccccccccc}
15,367 & 13,942 & 7,419 & 24,208 & 19,198 & 9,196 & 0 & 15,660 & 13,638 \\
31,747 & 5,852 & 23,799 & 18,974 & 13,964 & 6,464 & 16,380 & 0 & 19,524 \\
12,538 & 13,672 & 6,219 & 10,570 & 5,560 & 18,418 & 13,638 & 23,988 & 0 \\
\hline
\end{tabular}

\subsection{Menentukan Rute terpendek}

Berdasarkan hasil perhitungan algoritma Floyd-Warshall diperoleh hasil akhir iterasi $k=17$ sebagaimana yang termuat pada Tabel 5. Kemudian bobot hasil akhir iterasi algoritma Floyd Warshall dapat dibentuk graf hasil sebagai berikut.

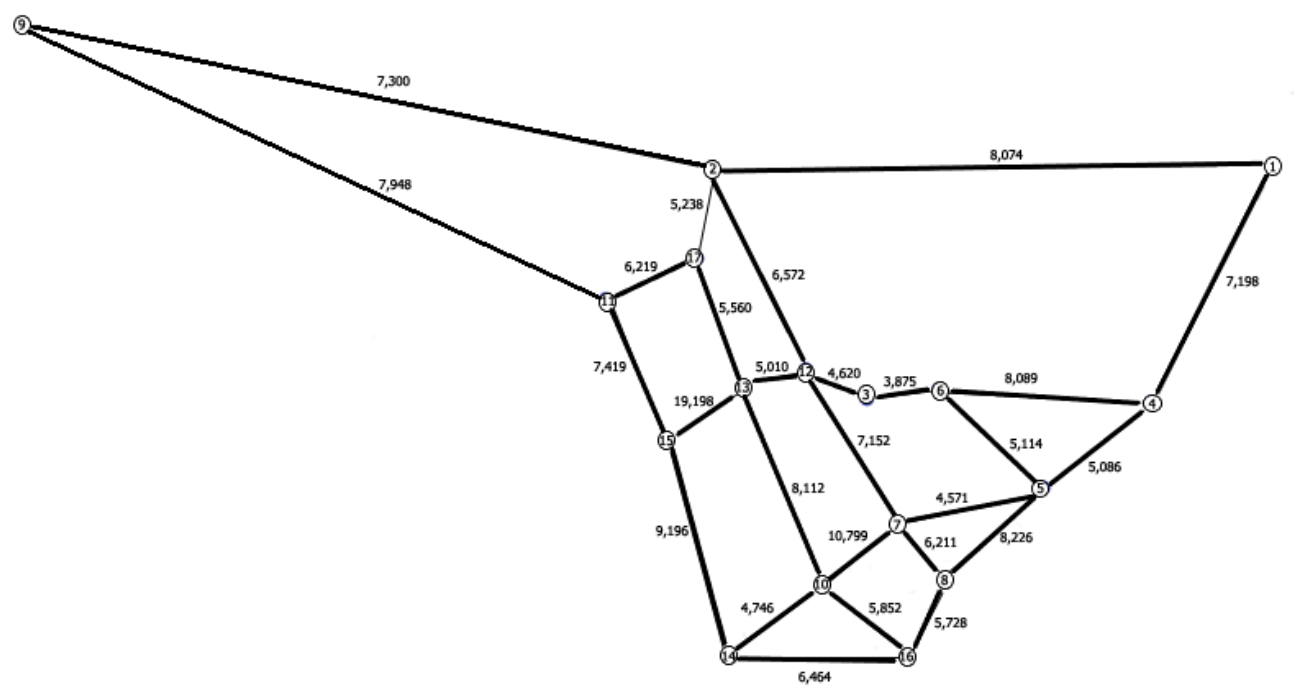

Gambar 2. Graf Hasil

Untuk dapat menentukan Rute terpendek pengangkutan Sampah di Kota Gorontalo kita dapat menganalisis bobot terkecil antar setiap edge yang menghubungkan masing masing titik(vertex) dengan ketentuan tidak terjadi loop (setiap lintasan(edge) hanya dapat dilalui sekali) . Berikut langkah langkahnya.

1. v1-v2 $=8,074, \mathbf{v 1 - v 4}=\mathbf{7 , 1 9 8}$ (edge v1-v4 dipilih karena bobotnya lebih kecil).

2. $\mathbf{v 4 - v 5}=\mathbf{5 , 0 8 6}, \mathrm{v} 4-\mathrm{v} 6=8,089$

3. v5-v8 $=8,226, \mathbf{v 5 - v 7}=\mathbf{4 , 5 7 1}$, v5-v7 $=5,114$, Dilakukan seterusnya hingga terbentuk rute dengan bobot minimum.

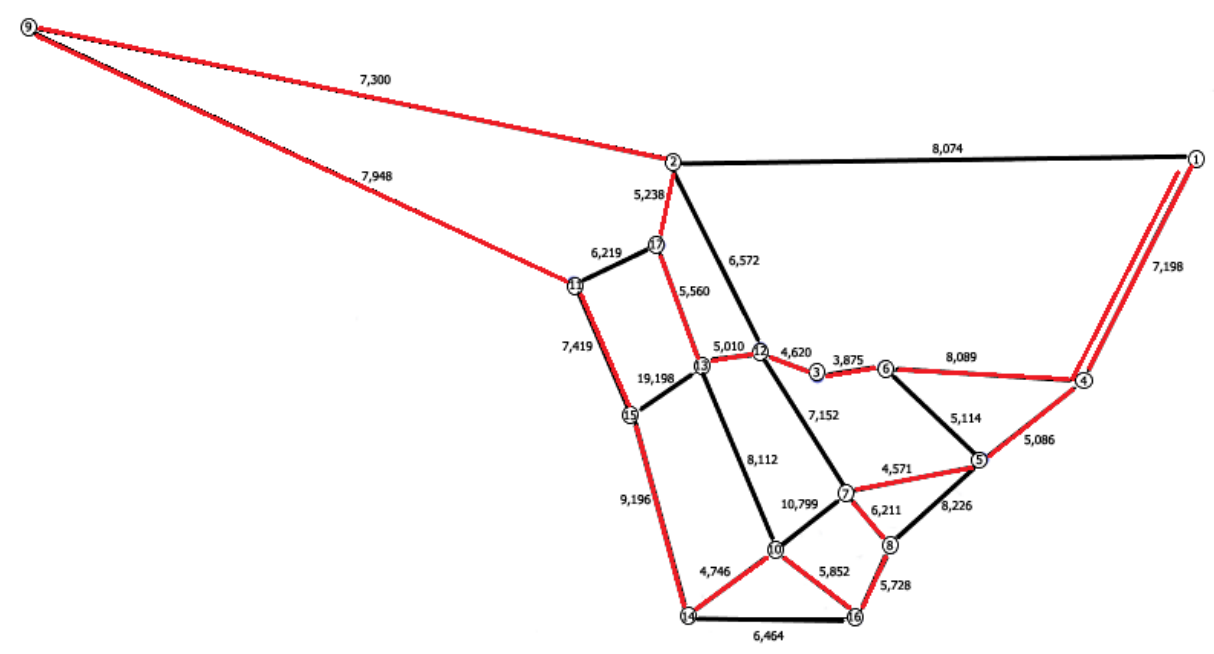

Gambar 3. Graf optimal 
Dengan melihat bobot terkecil antar setiap pasangan titik diperoleh Rute terpendek lintasan dari titik v1 kembali ke titik v1 dengan bobot lintasan optimum 110,845 dengan rute v1 - v4 - v5 - v7 - v8 - v16 - v10 - v14 - v15 - v11 - v9 - v2 - v17 - v13 - v12 - v3- v6 - v4 - v1. Untuk mengecek apakah rute yang diperoleh merupakan rute yang optimum, berikut penulis dapat membandingkan rute yang diperoleh dengan alternatif rute yang lainya.

Tabel 6. Perbandingan Rute

\begin{tabular}{ccc}
\hline No & Rute & Bobot \\
\hline 1. & v1-v4-v5-v7-v8-v16-v10-v14-v15-v11-v9-v2-v17-v13-v12-v3-v6-v4-v1 & 110,854 \\
2. & v1-v2-v17-v13-v12-v3-v6-v4-v5-v7-v8-v16-v10-v14-v15-v11-v9-v2-v1 & 112,597 \\
3. & v1-v4-v6-v3-v12-v13-v17-v2-v9-v11-v15-v14-v16-v10-v7-v8-v5-v4-v1 & 122,009 \\
4. & v1-v2-v9-v11-v15-v14-v16-v10-v7-v8-v5-v4-v6-v3-v12-v13-v17-v2-v1 & 123,041 \\
5. & v1-v4-v5-v7-v8-v16-v10-v14-v15-v13-v7-v11-v9-v2-v12-v3-v6-v4-v1 & 125,356 \\
6. & v1-v2-v12-v3-v6-v4-v5-v7-v8-v16-v10-v14-v15-v13-v17-v11-v9-v2-v1 & 128,637 \\
7. & v1-v4-v6-v3-v12-v2-v9-v11-v17-v13-v15-v14-v10-v16-v8-v7-v5-v4-v1 & 129,631 \\
\hline
\end{tabular}

Dapat dilihat bahwa rute yang diperoleh sebelumnya adalah rute dengan bobot terkecil bila dibandingkan dengan alternatif rute yang lainya. tentunya masih ada banyak alternatif rute lainya yang dapat dibentuk tetapi bobotnya tidak akan lebih kecil dari 110,854 sebab rute tersebut dibentuk dari lintasan (edge) dengan bobot terkecil yang menghubungkan antar vertex.

\section{Kesimpulan}

Berdasarkan deskripsi masalah dan pengolahan data yang telah dilakukan, maka dapat diambil kesimpulan bahwa metode yang digunakan dalam rute terpendek pengangkutan sampah di kota Gorontalo diselesaikan dengan Algoritma Floyd-Warshall (Tabel 5.) dengan pembobotan menggunakan metode Multi Atribute Decision Making (MADM) dapat dilihat pada Tabel 4. Atribut yang digunakan dalam penelitian ini yaitu jarak, waktu dan kemacetan. Adapun rute terpendek (optimum) pengangkutan sampah armada dumptruck yang diperoleh dari penelitian ini yaitu : Dinas Lingkungan Hidup - Jl. MT Haryono - Jl. 23 Januari - Jl. ST.Hasanudin - Jl. Melati Jl. Mawar - Jl. Gunung agung - Jl. Gunung krakatau - Jl. Katamso - Jl.Gunung Tilongkabila - Jl. Kancil - Jl.Raja Eyato - Jl. Jl. AR.Koniyo - Jl. Gunung Lokon - Jl. Gunung Boliyohuto Jl. Suprapto - Jl. S.Parman - Jl. MT.Haryono - Dinas Lingkungan Hidup . dengan bobot rute 110,854 .

\section{Referensi}

[1] F. Kuka, M. R. Katili, dan R. F. Payu, "Optimasi Pengangkutan Sampah di Kota Gorontalo dengan Model Vechile Routing Problem melalui pendekatan Goal Programing," Jurnal MUST: Mathematics Education, Science and Technology., Vol. 6, No. 1, Juli 2021.

[2] P. M. Hasugian, "Analisa dan Implementasi Algoritma Bellman Ford dalam menentukan jalur terpendek pengantaran barang Dalam Kota," Jurnal Mantik Penusa., Vol. 18, No. 2, pp. 118-123, Desember 2015.

[3] M. H. Anwar, A. Sanjaya, dan F. R. Hariri, "Sistem pendukung keputusan penentuan rute terdekat pada operator taxi untuk mencari tempat tujuan penumpang menggunakan algoritma Floyd-Warshall,” Jurnal Simki Techsain., Vol. 1, No. 1, pp. 4-15, Agustus 2017.

[4] F. W. Ningrum, T. Andrasto "Penerapan Algorima Floyd-Warshall dalam menentukan rute terpendek pada pemodelan jaringan pariwisata di kota semarang," Jurnal Teknik Elektro., Vol. 8, No. 1, pp. 21-24, Juni 2016. doi: 10.15294/jte.v8i1.8791.

[5] A. Muzakir, "Algoritma Floyd Warshall dan Collaborative Filtering untuk penentuan Rute Terpendek Pencarian Apotek," Jurnal Nasional Informatika dan Teknologi Jaringan., Vol. 5, No. 1, pp. 9-13, September 2020. doi: 10.30743/infotekjar.v5i1.2496 
[6] F. Fatmala, U. Yudatama, dan A. Burhanuddin, "Panduan Jalur Angkutan Umum Menggunakan Algoritma Floyd-Warshall," Jurnal Komtika., Vol. 3, No. 1, pp. 1-9, Mei 2019. doi: 10.31603/komtikav3i1.3462

[7] A. Rachman, H, Leidiyana, " Sistem Informasi Fasilitas di DKI Jakarta Berbasis Android dengan Algoritma Floyd Warshall," Jurnal Komtika., Vol. 4, No. 1, pp. 9-14, Mei 2020. doi: 10.31603/komtika.v4il.3700

[8] A. F. Sani, N. K. T. Tastrawati, dan I. M. E. Dwipayana, "Algoritma Floyd Warshall Untuk menentukan Jalur terpendek Evakuasi Tsunami di kelurahan Sanur". E-Journal Matematika., Vol.2, No.1, pp. 1-5, Januari 2013. doi :10.24843/MTK.2013.V02.i01.p020

[9] A. D. Yustita, S. A. Hardiyanti, dan I. Yuniawati, "Algoritma Floyd-Warshall untuk penentuan rute terpendek model jaringan pariwisata kabupaten Banyuwangi," Jurnal Matematika dan Pendidikan Matematika., Vol.3, No.2, pp 137-146, September 2018. doi: 10.26594/jmpm.v3i2.1299

[10] A. Aridhayanti, R A. Fadillah, "Implementasi Attribute Decision Making (MADM) Untuk menentukan kawasan penanaman Bakau”. Jurnal sains, teknologi dan industry., Vol.14, No.1, pp. 86-92, Desember 2016. doi:10.24014/sitekin.v14i1.2698

[11] K. A. P. Sari, E. Irawan, dan F. Rizky, "Implementasi Algoritma Weight Product (WP) Dengan Model Fuzzy Multi Attribute Decision Making (MADM) dalam Penilaian Kinerja Karyawan," Jurnal Penerapan Kecerdasan Buatan., Vol. 2, No. 1, pp. 57-65, Desember 2020.

[12] S. S. Priyono, W. W. Winarno, dan F. W. Wibowo, "Sistem Informasi untuk menentukan potensi mahasiswa menggunakan metode Fuzzy Multi Attribute Decision Making dengan Simple Additive Weighting Studi Kasus: STIKES Duta Gama," Jurnal Ilmiah Teknologi Informasi., Vol. 15, No.1, pp. 97-103, Maret 2020. doi: 10.35842/jtir.v15i1.339

[13] J. J. Siang, "Matematika Diskrit dan Aplikasinya pada ilmu Komputer," Andi, Yogyakarta. 2011.

[14] C. L. Liu, "Dasar Dasar Matematika Diskrit," Gramedia Pustaka Utama, Jakarta. 1995.

[15] S. Lipschuts, M. Lipson. "Matematika Diskrit Jilid 2 Schaum's " Salemba Teknika, Jakarta. 2002. 